\title{
OPTIMASI PRODUKSI HIDROLISAT PROTEIN IKAN KUNIRAN (Upeneus sulphureus) SECARA ENZIMATIS
}

\section{Optimizaton of Enzymatically Production of Fish Protein Hydrolysate from Kuniran (Upeneus sulphureus)}

\author{
Dewi Seswita Zilda, Gintung Patantis*, Yusro Nuri Fawzya, dan Pujoyuwono Martosuyono \\ Balai Besar Riset Pengolahan Produk dan Bioteknologi Kelautan dan Perikanan, \\ JI. KS Tubun Petamburan VI, Jakarta Pusat, DKI Jakarta, 10260, Indonesia \\ *Korespondensi Penulis: gintung.patantis@kkp.go.id
}

Diterima: 7 Juni 2021; Direvisi: 18 Agustus 2021; Disetujui: 18 Oktober 2021

\begin{abstract}
ABSTRAK
Karakteristik hidrolisat protein ikan (HPI) dipengaruhi oleh kondisi proses hidrolisisnya. Optimasi produksi HPI kuniran (Upeneus sulphureus) telah dilakukan secara enzimatis dengan perlakuan perbandingan ikan dan air (1:1 dan 1:2) dan penambahan enzim protease $500 \mathrm{U}$, $1.000 \mathrm{U}$, dan $1.500 \mathrm{U}$ per $25 \mathrm{~g}$ ikan. Nilai derajat hidrolisis (DH) HPI digunakan untuk menentukan kondisi optimum produksi HPI. Berdasarkan kondisi optimum tersebut, produksi HPI skala diperbesar dilakukan dengan $500 \mathrm{~g}$ ikan kuniran sebagai bahan baku. Karakteristik HPI skala diperbesar yang diamati adalah karakteristik kimia (air, abu, protein, lemak, asam amino, daya cerna protein, peptida, dan berat molekul) dan fisik (warna, aktivitas, dan stabilitas emulsi). Hasil penelitian menunjukkan bahwa perbandingan ikan, air, dan jumlah enzim berpengaruh terhadap nilai DH HPI. Pada skala produksi HPI diperbesar, karakteristik kimia dari HPI kuniran secara umum dipengaruhi oleh perbedaan perlakuan hidrolisis, tetapi tidak sifat fisiknya. Perbedaan kandungan protein, abu, dan peptida dari HPI lebih dominan dipengaruhi oleh perbedaan perlakuan perbandingan ikan dan air, sedangkan kombinasi perlakuan jumlah enzim dan perbandingan ikan dan air berpengaruh terhadap kandungan asam amino dan daya cerna protein $\mathrm{HPI}$. Secara umum, perlakuan hidrolisis menggunakan enzim $1.000 \mathrm{U} / 25 \mathrm{~g}$ dan perbandingan ikan dan air 1:1 (kode E1000A11) memberikan perlakuan terbaik yang terlihat dari kandungan protein, asam amino, peptida, dan daya cerna tertinggi dibandingkan perlakuan lain. Kandungan kimia dan daya cerna yang tinggi tersebut memberikan peluang aplikasi HPI sebagai penambah nutrisi bagi balita.
\end{abstract}

KATA KUNCI : enzimatis, hidrolisat protein ikan (HPI), ikan kuniran, optimasi produksi

\section{ABSTRACT}

The characteristics of fish protein hydrolyzate (FPH) are affected by their hydrolysis process conditions. Production optimization of FPH kuniran fish (Upeneus sulphureus) has been carried out enzymatically with treatments of fish and water ratio (1:1 and 1: 2 ) and protease enzymes 500 $\mathrm{U} ; 1,000 \mathrm{U}$, and 1,500 $\mathrm{U}$ per $25 \mathrm{~g}$ fish. The degree of hydrolysis $(\mathrm{DH})$ value of $\mathrm{FPH}$ was used to determine the optimum conditions of FPH production. Based on this optimum condition, the enlarged production of FPH (500 g of fish) was carried out. Chemical characteristics (moisture, ash, protein, fat, amino acids, protein digestibility, peptide, and molecular weight) and physical (color, the emulsion activity, and stability) of FPH from enlarged production were analyzed. The results showed that the ratio of fish and water and the amount of enzyme affect the $D H$ value of FPH. At the enlarged scale, the chemical characteristics of FPH kuniran were generally influenced by different hydrolysis treatments but not their physical properties. The differences in protein, ash, and peptide content of FPH were more dominantly affected by differences in the fish and water ratio, while the combination treatments of the enzymes and the ratio of fish-water affected the amino acid content and protein digestibility of FPH. In general, the hydrolysis treatment using a 1,000 $\mathrm{U}$ enzyme/25 $\mathrm{g}$ fish and the ratio of fish and water 1:1 (code E1000A11) was the optimum treatment as seen from the highest protein, amino acid, peptide, and protein digestibility compared to other treatments. The high chemical content and digestibility of FPH provide an opportunity application of FPH as a nutritional enhancer for toddlers.

KEYWORDS: enzymatic, fish protein hydrolyzate (FPH), kuniran fish, production optimization 


\section{PENDAHULUAN}

Ikan kuniran (Upeneus sulphureus) merupakan salah satu ikan demersal hasil samping tangkapan yang memiliki nilai ekonomis rendah. Ikan ini ditemukan hampir di seluruh wilayah perairan Indonesia dan memiliki kelimpahan yang cukup tinggi di wilayah pesisir Jawa (Wiadnyana, Badrudin, \& Aisyah, 2017). Pada tahun 2018, jumlah tangkapan ikan kuniran di perairan Indonesia mencapai 51.411 ton dan lebih dari $60 \%$ (34.940 ton) disumbang oleh tangkapan dari perairan Jawa Tengah (Kementerian Kelautan dan Perikanan, 2021). Hasil tangkapan ikan kuniran dimanfaatkan secara langsung untuk konsumsi dalam bentuk segar dan asin kering atau digunakan sebagai bahan baku pembuatan surimi. Dengan nilai ekonomis yang rendah, ikan kuniran dapat dijadikan sebagai bahan baku hidrolisat protein ikan (HPI), sehingga dapat meningkatkan nilai ekonominya.

HPI merupakan protein berukuran pendek (peptida) hasil hidrolisis protein ikan, baik secara kimiawi maupun enzimatis (He, Franco, \& Zhang, 2013; Kristinsson \& Rasco, 2000). Proses hidrolisis menggunakan enzim lebih dipilih karena proses dan produknya lebih terkontrol dibandingkan dengan hidrolisis secara kimia (Zamora-Sillero, Gharsallaoui, \& Prentice, 2018). Selain itu, proses enzimatis juga lebih ramah lingkungan dan produk yang dihasilkan lebih aman untuk diaplikasikan dalam industri makanan. Secara umum proses enzimatis mampu meningkatkan sifat fisika, kimia, sensori, dan fungsional HPI bila dibandingkan dengan protein ikan sebelum dihidrolisis (Kristinsson \& Rasco, 2000).

Enzim yang umum digunakan dalam produksi hidrolisat protein adalah protease, baik yang berasal dari hewan, tumbuhan maupun mikroorganisme. Beberapa enzim protease komersial yang tersedia di pasaran dan telah digunakan untuk produksi HPI antara lain papain dan bromelain yang berasal dari tumbuhan; alkalase, neutrase, dan flavourzyme protamex yang berasal dari mikroorganisme; serta pepsin, tripsin dan chymotipsin yang berasal dari saluran pencernaan (Fernandes, 2016; Siddik, Howieson, Fotedar, \& Partridge, 2021). Sebagian besar enzim komersial tersebut merupakan produk impor, oleh karena itu penggunaan enzim protease yang diproduksi secara mandiri akan mengurangi ketergantungan pada produk impor. Balai Besar Riset Pengolahan Produk dan Bioteknologi Kelautan dan Perikanan (BBRPPBKP) telah memiliki koleksi bakteri yang mampu memproduksi protease yang dapat diaplikasikan dalam proses produksi HPI.
Dalam proses hidrolisisnya, masing-masing enzim memiliki karakteristik yang berbeda. Beberapa faktor yang harus diperhatikan dalam proses produksi HPI mengggunakan enzim antara lain suhu, waktu, jenis substrat, enzim, dan konsentrasi enzim (Putalan, Munifah, Nurhayati, \& Chasanah, 2018; Utomo, Suryanigrum, \& Harianto, 2014). Faktor-faktor tersebut akan berpengaruh terhadap kecepatan dan produk HPI yang dihasilkan. Waktu hidrolisis merupakan faktor utama yang sangat berpengaruh terhadap kualitas produk HPI. Waktu hidrolisis yang berlebihan akan menyebabkan penurunan jumlah peptida dan asam amino fungsional (Utomo et al., 2014).

Beberapa laporan tentang optimasi produksi HPI secara enzimatis dengan jenis enzim dan ikan yang berbeda telah dilaporkan. Ariyani, Saleh, Tazwir, dan Hak (2003) melakukan optimasi produksi HPI dari ikan mujair (Oreochromis mossambicus) menggunakan enzim papain, sedangkan Utomo et al. (2014) menggunakan enzim papain untuk menghidrolisis limbah filet ikan patin (Pangasius sp.). Hasil kedua penelitian tersebut menyebutkan bahwa HPI terbaik dihasilkan dari waktu masing-masing 2 dan 4 hari dengan konsentrasi enzim papain $4 \%$ dan $10 \%(b / b)$. Proses hidrolisis limbah pengolahan ikan nila (Oreochromis niloticus) terbaik diperoleh dari perlakuan pemberian enzim bromelin selama 5 jam (Prasetyo, Sarmin, Setyastuti, \& Kurniawati, 2020), sedangkan hidrolisis ikan wader (Rasbora jacobsoni) terbaik diperoleh dari komposisi pemberian 40\% enzim calotropin dan $60 \%$ papain (Witono, Maryanto, Taruna, Masahid, \& Cahyaningati, 2020). Penelitian lain produksi HPI dari ikan selar (Selaroides leptolepis) menggunakan enzim protease yang diproduksi oleh Bacillus sp. koleksi BBRPPBKP menunjukan derajat hidrolisis optimum pada produksi selama 6 jam (Putalan et al., 2018). Selanjutnya, produksi HPI kuniran pada skala $30 \mathrm{~kg}$ ikan/60 L pelarut selama 6 jam menggunakan jumlah protease $20.000 \mathrm{U} / \mathrm{kg}$ bahan baku ikan masih menyisakan residu dengan kadar protein yang cukup tinggi (Martosuyono, Fawzya, Patantis, \& Sugiyono, 2019). Hal tersebut bisa disebabkan karena kurangnya jumlah enzim yang digunakan maupun perbandingan ikan dan air yang terlalu besar sehingga masih diperlukan perbaikan proses hidrolisisnya. Tujuan dari penelitian ini untuk optimasi produksi HPI dari ikan kuniran menggunakan enzim protease dari Bacillus sp. koleksi BBRPPBKP dengan parameter perlakuan berupa konsentrasi enzim dan perbandingan ikan dan air. HPI yang diperoleh selanjutnya dikarakterisasi sifat kimia dan fisiknya. 


\section{BAHAN DAN METODE}

\section{Bahan}

Ikan kuniran yang digunakan dalam penelitian ini diperoleh dari tempat pelelangan ikan di Tegal, Jawa Tengah. Enzim protease yang digunakan dalam proses hidrolisis adalah enzim yang diproduksi dari Bacillus sp. koleksi BBRPPBKP dengan aktivitas total $340 \mathrm{U} / \mathrm{mL}$. Semua bahan kimia yang digunakan merupakan pro analisis, seperti trichloro acetic acid (TCA) (Merck) dan Pierce ${ }^{\mathrm{TM}}$ Coomassie Plus (Bradford) Assay Kit (Thermo Fisher Scientific, USA).

\section{Metode}

\section{Produksi hidrolisat protein ikan kuniran}

Ikan kuniran dibersihkan isi perut dan sisiknya, kemudian bagian kepalanya dibuang. Bagian tubuh ikan kuniran termasuk tulang selanjutnya digiling menjadi ikan lumat. Ikan lumat yang diperoleh digunakan dalam proses produksi HPI yang mengacu pada Martosuyono et al. (2019). Percobaan hidrolisis ikan kuniran dilakukan dalam dua tahapan percobaan. Percobaan pendahuluan dilakukan untuk menentukan perbandingan ikan dan air (b/v) (1:1 dan 1:2) dan penambahan enzim (total aktivitas $500 \mathrm{U} ; 1.000 \mathrm{U}$ dan $1.500 \mathrm{U}$ ) yang optimum. Ikan lumat sebanyak 25 g ditambah air dengan perbandingan tertentu dan dihomogenisasi. Campuran kemudian dipanaskan sampai suhu $55^{\circ} \mathrm{C}$ lalu ditambah enzim dengan total aktivitas sesuai perlakuan dan dinkubasi selama enam jam. Reaksi hidrolisis dihentikan dengan memanaskan campuran pada suhu $100^{\circ} \mathrm{C}$ selama 10 menit. Larutan kemudian disentrifus pada kecepatan 8.000xg selama 10 menit untuk memisahkan HPI cair dan sisa padatan. Penentuan kondisi optimum ditentukan berdasarkan nilai derajat hidrolisis (DH). Kondisi optimum yang diperoleh (perbandingan ikan, air, dan konsentrasi enzim) dari tahap pertama digunakan untuk memproduksi hidrolisat tahap kedua dengan skala diperbesar ( $500 \mathrm{~g}$ daging ikan). HPI cair yang diperoleh dari proses kedua dikeringkan dengan spray dryer dengan penyalut maltodextrin $20 \%$ (Fawzya et al., 2017). HPI bubuk kemudian dianalisis sifat kimia dan fisiknya dengan dua kali ulangan.

\section{Derajat hidrolisis (DH)}

Penentuan DH HPI dilakukan dengan mengukur kadar protein terlarut (Bradford) dari HPI cair yang diperlakukan penambahan Trichloro acetic acid (TCA) dan tanpa penambahan TCA. Metode ini merupakan modifikasi dari metode nitrogen total (Hoyle \& Merritt, 1994). Perlakuan penambahan TCA dilakukan dengan menambahkan HPI cair dan TCA 6,25\% (b/v) dengan perbandingan 3:2. Campuran didiamkan pada suhu ruang selama 15 menit kemudian disentrifus dengan kecepatan $8.000 x g$ selama 15 menit. Supernatan yang terbentuk diukur protein terlarutnya menggunakan Pierce ${ }^{\mathrm{TM}}$ Coomassie Plus (Bradford) Assay Kit (Thermo Fisher Scientific, USA) dan dibandingkan dengan kadar protein tanpa perlakuan penambahan TCA. Nilai DH diukur dengan rumus:

$$
\mathrm{DH}(\%)=\frac{\begin{array}{c}
\text { Nilai protein terlarut } \\
\text { penambahan TCA }
\end{array}}{\begin{array}{c}
\text { Nilai protein terlarut tanpa } \\
\text { penambahan TCA }
\end{array}} \times 100 \%
$$

\section{Rendemen dan Karakteristik HPI}

Rendemen HPI cair pada penelitian tahap kedua dihitung berdasarkan formula:

$$
\underset{\text { cair }(\%)}{\text { Rendemen HPI }}=100 \%-\left(\left(\frac{\text { Berat residu }}{\begin{array}{c}
\text { Berat bahan } \\
\text { baku }
\end{array}}\right) \times 100 \%\right)
$$

Rendemen HPI sesudah proses spray drying dihitung dengan formula:

$$
\begin{gathered}
\text { Rendemen HPI } \\
\text { bubuk }(\%)
\end{gathered}=\frac{\text { Berat HPI }}{\text { Berat maltodekstrin }} \times 100 \%
$$

Pengamatan karakteristik HPI dilakukan terhadap nilai proksimat yang meliputi kadar air (SNI 2354.2:2015)(BSN, 2015), kadar abu (SNI 2354.1:2010)(BSN, 2010), kadar protein (modifikasi SNI 01-2354-4:2006), dan kadar lemak (SNI 2354.3:2017)(BSN, 2017). Analisis kandungan asam amino (Nollet \& Toldrá, 2012), peptida (Auwal, Zarei, Abdul-Hamid, \& Saari, 2017), berat molekul (Haider, Reid, \& Sharp, 2012), dan daya cerna protein (Gehrt, 1971) ditentukan sesuai dengan metode yang terdapat pada referensi tersebut. Karakteristik fisik HPI yang diamati meliputi warna (Hutchings, Luo, \& Ji, 2012), aktivitas dan stabilitas emulsi (Volkert \& Klein, 1979). Setiap pengukuran dilakukan sebanyak tiga kali. Analisis data dilakukan dengan uji ANOVA dan uji lanjut Tukey.

\section{HASIL DAN PEMBAHASAN}

\section{Nilai DH Optimum}

Nilai DH dari perlakuan jumlah enzim dan perbandingan ikan dan air HPI kuniran disajikan pada Tabel 1. Hasil analisis statistik menunjukkan perbedaan yang signifikan dari masing-masing 
perlakuan terhadap nilai $\mathrm{DH}(p<0,05)$. Perlakuan perbandingan ikan dan air 1:1 menghasilkan $\mathrm{DH}$ lebih tinggi dari perbandingan 1:2, sedangkan perlakuan pemberian enzim $1.500 \mathrm{U} / 25 \mathrm{~g}$ menghasilkan DH lebih tinggi dari dua perlakuan lain, tetapi hanya berbeda nyata terhadap perlakuan enzim $500 \mathrm{U} / 25 \mathrm{~g}$.

Nilai DH banyak digunakan untuk menentukan kondisi optimum proses hidrolisis menggunakan enzim (García Moreno et al., 2017; Kristinsson \& Rasco, 2000; Noman et al., 2018). Pengukuran DH umumnya menggunakan metode $\mathrm{pH}$, osmometer, OPA dan nitrogen total (Hoyle \& Merritt, 1994; Kristinsson \& Rasco, 2000; Nielsen, Petersen, \& Dambmann, 2001), sedangkan penentuan $\mathrm{DH}$ yang digunakan pada penelitian ini menggunakan metode protein terlarut. Penggunaan metode ini dipilih karena kemudahan dalam analisis.

Hasil dari penelitian ini selaras dengan hasil yang telah dilaporkan bahwa nilai $\mathrm{DH}$ dipengaruhi oleh beberapa faktor, antara lain jumlah enzim, perbandingan enzim dan substrat, serta waktu hidrolisis (Kristinsson \& Rasco, 2000). Penelitian lain juga menyebutkan bahwa rasio substrat dan air sebesar 1:1 memberikan nilai DH tertinggi (metode $\mathrm{pH}$ ) dibandingkan dengan perbandingan substrat dan air sebesar 1:2, 1:3, dan 1:4 (Noman et al., 2018). Perbandingan substrat dan air yang cukup akan memudahkan proses pencampuran enzim dan substrat yang akan memudahkan proses hidrolisis. Setelah melewati titik optimum, proses hidrolisis tidak akan meningkat secara signifikan (Benjakul \& Morrissey, 1997).

Pada penelitian ini pemberian enzim sama dengan atau lebih dari $1.000 \mathrm{U}$ tidak menghasilkan nilai $\mathrm{DH}$ yang berbeda secara signifikan. Hal ini selaras dengan penelitian Noman et al. (2018) yang menyatakan bahwa peningkatan jumlah enzim akan meningkatkan nilai $\mathrm{DH}$, tetapi setelah mencapai jumlah enzim optimum, nilai DH akan menurun. Penelitian tersebut juga menyatakan bahwa jumlah enzim yang berlebihan akan menyebabkan proses difusi enzim ke dalam substrat terhambat karena adanya agregasi enzim. Lebih jauh proses ini meyebabkan reaksi hidrolisis mengalami kejenuhan. Penggunaan air dan enzim yang berlebihan juga akan meningkatkan biaya produksi dan energi yang dikeluarkan dalam proses produksi HPI pada skala besar. Perlakuan terbaik, enzim $1.000 \cup(E 1000)$, perbandingan ikan dan air 1:1 (A11) dan 1:2 (A12) digunakan untuk penelitian tahap selanjutnya (produksi HPI skala $500 \mathrm{~g}$ ). Sebagai pembanding digunakan perlakuan enzim $500 \mathrm{U}$ (E500) dan perbandingan ikan dan air 1:2 (A12).

\section{Produksi HPI Skala $500 \mathrm{~g}$}

Produksi HPI skala $500 \mathrm{~g}$ dilakukan menggunakan perlakuan E1000A11 dan E1000A12. Rendemen HPI cair dan setelah proses spray drying (HPI bubuk) ditunjukkan pada Gambar 1. Perlakuan enzim (E) dan perbandingan ikan dan air $(A)$ memberikan perbedaan rendemen yang signifikan pada HPI cair tetapi tidak untuk HPI padat. Rendemen tertinggi HPI cair diperoleh dari perlakuan hidrolisis menggunakan perlakuan E1000A12. Sedangkan pada perlakuan E1000A11, rendemen HPI cair yang diperoleh lebih rendah dari pada perlakuan E500A12. Penggunaan enzim dalam jumlah yang lebih banyak dan optimum (1.000 U) akan menghidrolisis ikan secara optimum sehingga rendemen $\mathrm{HPI}$ yang dihasilkan juga tinggi. Sedangkan pada perlakuan perbandingan ikan dan air 1:1, E1000A11 meskipun menggunakan enzim yang lebih banyak dari E500A12, tetapi rendemen yang dihasilkan lebih rendah. Hal ini karena penggunaan air yang lebih banyak akan memudahkan proses pencampuran enzim dan substrat dan lebih banyak ikan yang terlarut, walaupun pada nilai $\mathrm{DH}$ menunjukan yang sebaliknya.

Tabel 1. Derajat hidrolisis HPI kuniran dengan perlakuan hidrolisis yang berbeda

Table 1. Degree of hydrolysis of FPH kuniran with different treatments

\begin{tabular}{lcccc}
\hline \multirow{2}{*}{\begin{tabular}{c}
\multirow{2}{*}{ Perlakuan/Treatments } \\
\cline { 2 - 4 }
\end{tabular}} & \multicolumn{3}{c}{ Derajat Hidrolisis/Degree of Hydrolysis (\%) } \\
\cline { 2 - 4 } & $1: 1$ & $\mathbf{5 0 0}$ & $\mathbf{1 , 0 0 0}$ & $\mathbf{1 , 5 0 0}$ \\
\hline \multirow{2}{*}{$\begin{array}{c}\text { Rasio ikan dan air/ } \\
\text { Fish and water ratio }\end{array}$} & $1: 2$ & $60.25 \pm 3.39^{\mathrm{Ab}}$ & $83.88 \pm 1.42^{\mathrm{Aa}}$ & $82.11 \pm 0.57^{\mathrm{Aa}}$ \\
\hline
\end{tabular}

Keterangan/Notes: Perbedaan huruf kapital menunjukan perbedaan secara signifikan pada perlakuan perbandingan ikan dan air, sedangkan pada huruf kecil pada perlakuan pemberian enzim $(p<0,05) /$ Different capital letters show significantly different of fish and water ratio, while different small letters show different of enzyme number $(p<0.05)$ 


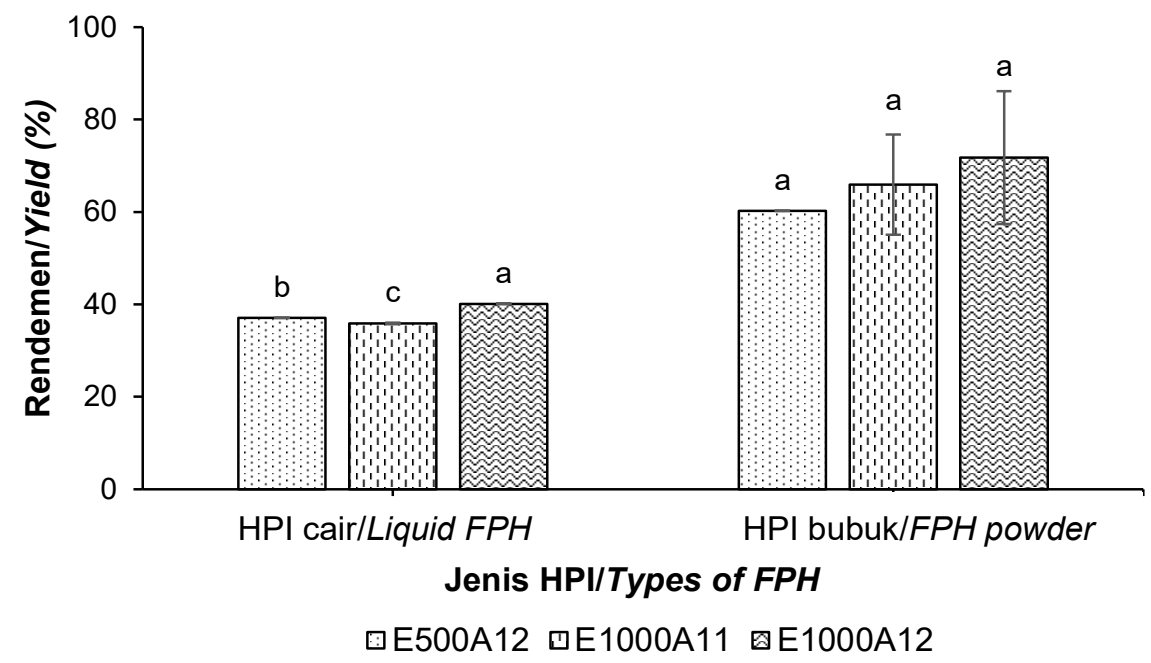

Keterangan/Notes: Perbedaan huruf pada grafik menunjukan perbedaan nyata $(p<0,05)$ antar perlakuan hidrolisis pada jenis HPI yang sama/Different letters at the graph show significantly different

Gambar 1. Rendemen HPI kuniran produksi hidrolisis skala 500 g, E500A12: Enzim 500 U/25 g, perbandingan ikan dan air 1:2; E1000A11: Enzim $1.000 \mathrm{U} / 25 \mathrm{~g}$, perbandingan ikan dan air 1:1; E1000A12: Enzim $1.000 \mathrm{U} / 25 \mathrm{~g}$, perbandingan ikan dan air 1:2.

Figure 1. Yield of FPH kuniran from $500 \mathrm{~g}$ of hydrolysis production, E500A12: $500 \mathrm{U}$ of enzyme/25 g, 1: 2 of fish and water ratio; E1000A11: 1,000 U of enzyme/25 g, 1: 1 of fish and water ratio; E1000A 12: 1,000 U of enzyme/25 g, 1: 2 of fish and water ratio.

\section{Efek Perlakuan Hidrolisis terhadap Karakteristik Kimia HPI}

\section{Proksimat}

Perlakuan jumlah enzim dan perbandingan ikan dan air dalam hidrolisis ikan kuniran berpengaruh terhadap komposisi proksimat HPI yang dihasilkan (Tabel 2). Dari keempat parameter proksimat (air, abu, protein, dan lemak), kandungan abu dan protein HPI berbeda nyata terhadap respon perlakuan jumlah enzim dan perbandingan ikan dan air, sedangkan kadar air dan lemak tidak dipengaruhi oleh adanya perbedaan perlakuan. Jika dilihat lebih dalam lagi, pada perlakuan E500A12 dan E1000A12, kadar abu dan proteinnya tidak berbeda nyata antara keduanya. Hal ini mengindikasikan bahwa walaupun penambahan jumlah enzim berbeda (500 U dan $1.000 \mathrm{U}$ ), jika perbandingan ikan dan air nya sama (1:2) maka jumlah protein dan abu yang dihasilkan tidak berbeda nyata. Hal ini berbeda dengan perlakuan perbandingan ikan dan air 1:1 (E1000A11) yang menghasilkan HPI dengan kandungan protein dan abu yang berbeda dan paling tinggi $(22,73 \pm 0,77 \%$ dan $2,22 \pm 0,40 \%)$ dari kedua perlakuan sebelumnya. Hasil tersebut kemungkinan disebabkan karena jumlah penambahan air yang lebih sedikit dibandingkan dengan perbandingan $1: 2$, sehingga faktor pengencerannya lebih kecil (proporsi daging ikan di dalam campuran lebih besar). Hal ini mengindikasikan perlakuan perbandingan ikan dan air lebih dominan berpengaruh terhadap karakteristik protein dan abu dibandingkan dengan perlakuan jumlah enzim $500 \mathrm{U}$ dan $1.000 \mathrm{U}$.

Beberapa penelitian telah melaporkan komposisi proksimat dari HPI yang diproduksi secara enzimatis (Chalamaiah, Hemalatha, \& Jyothirmayi, 2012), tetapi yang melaporkan efek jumlah enzim dan perbandingan ikan dan air terhadap proksimat HPI masih jarang dilakukan. Penelitian-penelitian tersebut hanya membandingkan pengaruhnya terhadap nilai $\mathrm{DH}$ (Noman et al., 2018) atau protein terlarut (Srikanya, Dhanapal, Sravani, Madhavi, \& Praveen, 2017). Bila dibandingkan dengan dua produk susu bubuk komersial yang mengandung protein hidrolisat $(17,38$ dan 14,48\%) (Fawzya et al., 2017), nilai protein HPI ikan kuniran dari semua perlakuan (17,97-22,73 \%) mempunyai nilai yang lebih tinggi. Nilai protein yang tinggi ini memberikan potensi aplikasi HPI ikan kuniran sebagai penambah nutrisi bagi balita.

\section{Asam amino}

Secara umum komposisi asam amino HPI ikan kuniran dipengaruhi oleh perlakuan hidrolisis, jumlah enzim, serta perbandingan ikan dan air (Tabel 3). Sedangkan tiga jenis asam amino (arginina, histidina, 
Tabel 2. Komposisi proksimat HPI ikan kuniran dengan perlakuan hidrolisis konsentrasi enzim, dan perbandingan ikan dan air yang berbeda.

Table 2. Proximate composition of FPH kuniran fish with different hydrolysis treatments of enzyme concentration and fish and water ratio.

\begin{tabular}{ccccc}
\hline \multirow{2}{*}{$\begin{array}{c}\text { Perlakuan Hidrolisis/ } \\
\text { Hydrolysis Treatments }\end{array}$} & \multicolumn{3}{c}{ Komposisi Proksimat HPI/Proximate Composition of FPH (\%) } \\
\cline { 2 - 5 } & $\begin{array}{c}\text { Kadar Air/ } \\
\text { Moisture Content }\end{array}$ & $\begin{array}{c}\text { Kadar Abu/ } \\
\text { Ash Content }\end{array}$ & $\begin{array}{c}\text { Kadar Protein/ } \\
\text { Protein Content }\end{array}$ & $\begin{array}{c}\text { Kadar Lemak/ } \\
\text { Fat Content }\end{array}$ \\
\hline E500A12 & $4.48 \pm 0.14^{\mathrm{a}}$ & $1.74 \pm 0.04^{\mathrm{b}}$ & $19.17 \pm 0.02^{\mathrm{b}}$ & $0.30 \pm 0.01^{\mathrm{a}}$ \\
E1000A11 & $4.74 \pm 0.08^{\mathrm{a}}$ & $2.22 \pm 0.40^{\mathrm{a}}$ & $22.73 \pm 0.77^{\mathrm{a}}$ & $0.22 \pm 0.19^{\mathrm{a}}$ \\
E1000A12 & $5.04 \pm 0.40^{\mathrm{a}}$ & $1.62 \pm 0.08^{\mathrm{b}}$ & $17.97 \pm 1.01^{\mathrm{b}}$ & $0.23 \pm 0.08^{\mathrm{a}}$ \\
\hline
\end{tabular}

Keterangan/Notes: Perbedaan huruf pada kolom yang sama menunjukan perbedaan nyata $(p<0,05) /$ Different letters at the same column show significantly different $(p<0.05)$

dan tirosina) dari 15 asam amino yang dianalisis mempunyai nilai tidak berbeda nyata dan ketiganya merupakan asam amino non esensial. Berdasarkan total asam amino, perlakuan E500A12 dan E1000A11 memberikan hasil terbaik dengan jumlah asam amino masing-masing 155,62 $\pm 0,22$ dan 153,29 $\pm 0,31 \mu \mathrm{g} / \mathrm{mg}$. Kedua perlakuan tersebut juga memberikan nilai tertinggi pada hampir semua jenis asam amino kecuali fenilalanina yang nilainya lebih rendah daripada perlakuan E1000A12. Hasil di atas mengindikasikan bahwa pada perlakuan enzim yang sama $(1.000 \mathrm{U})$ dan perbandingan air dan ikan berpengaruh terhadap asam amino, dan pada perlakuan perbandingan ikan dan air yang sama (1:2), jumlah enzim berpengaruh terhadap kandungan asam amno. Hasil ini sedikit berbeda dengan kandungan protein pada masingmasing jenis perlakuan, yaitu jumlah enzim kurang dominan pengaruhnya (Tabel 2). Jenis asam amino

Tabel 3. Komposisi asam amino HPI ikan kuniran dengan perlakuan hidrolisis jumlah enzim, dan perbandingan ikan dan air yang berbeda.

Table 3. Amino acids composition of FPH kuniran fish with different hydrolysis treatments of enzyme number and fish and water ratio.

\begin{tabular}{|c|c|c|c|c|}
\hline \multirow[b]{2}{*}{$\begin{array}{l}\text { Asam Amino/ } \\
\text { Amino Acids }\end{array}$} & \multicolumn{4}{|c|}{ Kandungan Asam Amino/Amino Acid Content ( $\mu \mathrm{g} / \mathrm{mg})$} \\
\hline & E500A12 & E1000A11 & E1000A12 & $\begin{array}{c}\text { Susu Formula Balita } \\
\text { Komersial/ } \\
\text { Commercial Toddler } \\
\text { Milk Formula } \\
\text { (Fawzya et al., 2017) }\end{array}$ \\
\hline Leusina/Leucine* & $11.06 \pm 0.04^{b}$ & $11.60 \pm 08^{a}$ & $9.82 \pm 0.13^{c}$ & 9.88 \\
\hline Lisina/Lysine* & $21.22 \pm 0.11^{a}$ & $20.94 \pm 0.13^{a}$ & $15.92 \pm 0.18^{b}$ & 7.77 \\
\hline Isoleusina/soleucine* & $5.00 \pm 0.08^{a}$ & $4.94 \pm 0.04^{\mathrm{a}}$ & $4.58 \pm 0.02^{b}$ & 3.07 \\
\hline Fenilalanina/ Phenylalanine* & $4.06 \pm 0.01^{\mathrm{c}}$ & $4.62 \pm 0.05^{\mathrm{b}}$ & $5.51 \pm 0.00^{\mathrm{a}}$ & 3.10 \\
\hline Treonina/Threonine* & $6.76 \pm 0.01^{\mathrm{a}}$ & $6.24 \pm 0.05^{\mathrm{b}}$ & $6.18 \pm 0.04^{\mathrm{b}}$ & 5.61 \\
\hline Valina/Valine* & $6.90 \pm 0.02^{\mathrm{a}}$ & $6.52 \pm 0.04^{b}$ & $6.12 \pm 0.06^{\mathrm{c}}$ & 2.64 \\
\hline Alanina/Alanine & $12.52 \pm 0.04^{a}$ & $12.50 \pm 0.09^{a}$ & $10.14 \pm 0.12^{b}$ & 5.72 \\
\hline Arginina/Arginin & $9.34 \pm 0.64^{a}$ & $9.26 \pm 0.04^{\mathrm{a}}$ & $9.02 \pm 0.10^{a}$ & 1.94 \\
\hline Asam aspartat/Aspartic Acid & $17.58 \pm 0.08^{\mathrm{a}}$ & $15.62 \pm 0.09^{b}$ & $14.32 \pm 0.16^{\mathrm{c}}$ & 11.92 \\
\hline Asam glutamat/G/utamic acid & $32.24 \pm 0.06^{a}$ & $31.60 \pm 0.21^{a}$ & $27.03 \pm 0.23^{b}$ & 15.74 \\
\hline Glisina/Glycine & $10.08 \pm 0.01^{b}$ & $11.30 \pm 0.11^{\mathrm{a}}$ & $9.36 \pm 0.11^{c}$ & 3.00 \\
\hline Histidina/Histidine & $3.11 \pm 0.07^{\mathrm{a}}$ & $3.05 \pm 0.04^{a}$ & $3.05 \pm 0.00^{\mathrm{a}}$ & 1.36 \\
\hline Prolina/Proline & $7.02 \pm 0.04^{a}$ & $6.18 \pm 0.04^{b}$ & $6.20 \pm 0.07^{b}$ & 4.76 \\
\hline Serina/Serine & $6.11 \pm 0.03^{a}$ & $6.10 \pm 0.00^{a}$ & $5.49 \pm 0.08^{b}$ & 6.34 \\
\hline Tirosina/Tyrosine & $2.60 \pm 0.00^{a}$ & $2.86 \pm 0.69^{a}$ & $2.46 \pm 0.01^{a}$ & 2.57 \\
\hline Total & $155.62 \pm 0.22^{a}$ & $153.29 \pm 0.31^{a}$ & $135.21 \pm 1.33^{\mathrm{b}}$ & 85.42 \\
\hline
\end{tabular}

Keterangan/Notes: Perbedaan huruf pada kolom yang berbeda menunjukan perbedaan nyata $(p<0,05) /$ Different letters at the different columns show significantly different $(p<0.05)$ 
tertinggi yang teridentifikasi pada semua perlakuan adalah asam glutamat. Asam glutamat merupakan salah satu asam amino dengan kandungan tertinggi selain asam aspartat yang banyak ditemukan pada produk perikanan dan HPI (Ariyani et al., 2003; Noman et al., 2018). Kandungan asam amino dari HPI ikan kuniran juga tercatat lebih tinggi dari susu formula balita komersial (Fawzya et al., 2017). Kandungan asam amino HPI yang tinggi ini membuka prospek untuk diaplikasikan sebagai penambah nutrisi bagi balita.

\section{Daya cerna protein}

Daya cerna HPI ikan kuniran dengan perlakuan hidrolisis yang berbeda ditunjukkan pada Gambar 2. Daya cerna HPI dipengaruhi oleh perbedaan jenis perlakuan hidrolisis $(p<0,05)$. Nilai daya cerna tertinggi $(98,66 \pm 0,29 \%)$ didapatkan dari perlakuan penambahan enzim $1.000 \mathrm{U}$ dan perbandingan ikan dan air 1:1 (E1000A11). Nilai ini berbeda nyata dengan daya cerna HPI dari perlakuan E500A12 $(97,95 \pm 0,16 \%)$ tetapi tidak berbeda dengan perlakuan E1000A12 (97,38 $\pm 0,37 \%)$. Sedangkan perlakuan E500A12 dan E1000A12 tidak memberikan pengaruh yang nyata dalam nilai daya cerna. Hasil di atas mengindikasikan bahwa gabungan perlakuan penambahan enzim dan perbandingan ikan dan air akan menghasilkan nilai daya cerna yang berbeda. Ketiga perlakuan di atas juga menghasilkan HPI dengan daya cerna yang lebih tinggi dari daya cerna ikan kuniran sebagai bahan baku (Fawzya et al., 2017) dan standar hidrolisat protein untuk pangan (97\%) (Nurhayati, Salamah, Cholifah, \& Nugraha, 2014).

\section{Kandungan dan berat molekul peptida}

Kandungan peptida HPI dipengaruhi oleh perlakuan hidrolisis (Gambar 3). Nilai tertinggi didapatkan pada perlakuan pemberian enzim $1.000 \mathrm{U}$ dan perbandingan ikan dan air 1:1 (E1000A11) dengan jumlah peptida $0,15 \pm 0,008 \mathrm{mg}$ L-Glutation/mg HPI. Nilai tersebut berbeda nyata $(p<0,05)$ dengan kandungan peptida pada perlakuan E500A12 dan E1000A12. Sedangkan kandungan peptida keduanya masing-masing sebesar $0,12 \pm 0,006$ dan $0,13 \pm 0,006 \mathrm{mg}$ L-Glutation/mg HPI yaitu keduanya tidak berbeda nyata. Hasil tersebut mengindikasikan bahwa jumlah kombinasi enzim dan perbandingan ikan dan air kemungkinan berpengaruh terhadap kandungan peptida HPI pada penelitian ini. Hasil kandungan peptida ini juga selaras dengan hasil kandungan protein dari masing-masing perlakuan (Tabel 2). Secara umum peningkatan jumlah enzim dalam proses hidrolisis mampu meningkatkan kandungan nitrogen HPI sampai pada titik tertentu (Kristinsson \& Rasco, 2000).

Profil SDS-PAGE HPI ikan kuniran dengan perlakuan hidrolisis yang berbeda ditunjukan pada Gambar 4. Secara umum, berat molekul HPI ikan kuniran memiliki profil yang sama pada setiap perlakuan yaitu didominasi oleh hidrolisat dengan ukuran 6,5-17,0 KDa. Kemiripan tersebut kemungkinan disebabkan karena penggunaan enzim yang sama dalam proses hidrolisis. Sedangkan

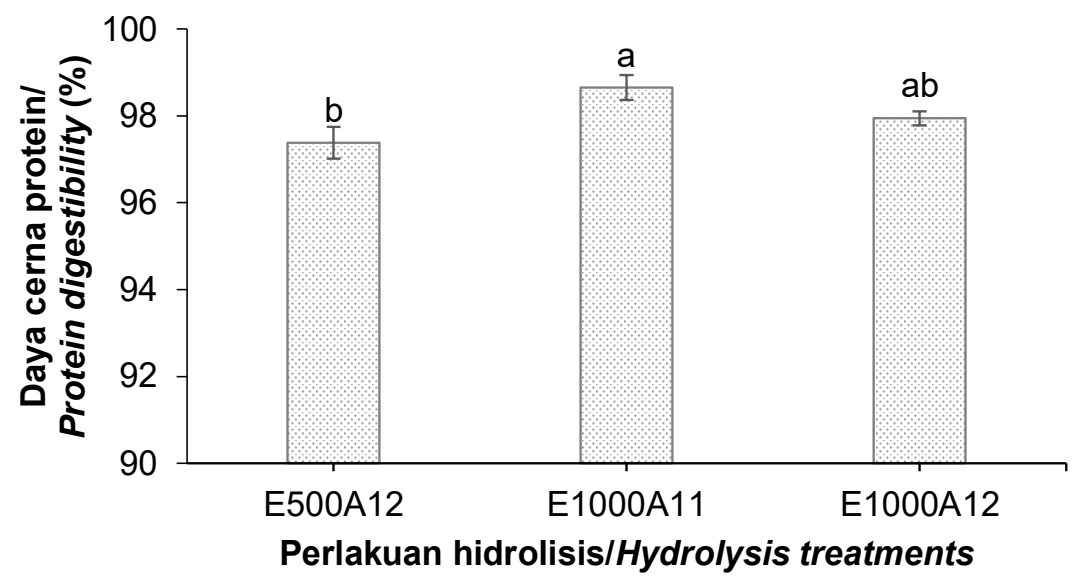

Keterangan/Notes: Perbedaan huruf pada grafik menunjukkan perbedaan nyata $(p<0,05) / D i f f e r e n t$ letters at the graph show significantly different $(p<0.05)$

Gambar 2. Nilai daya cerna protein HPI ikan kuniran dengan perlakuan hidrolisis konsentrasi enzim, dan perbandingan ikan dan air yang berbeda

Figure 2. Protein digestibility of FPH kuniran fish with different hydrolysis treatments of enzyme concentration and fish and water ratio 


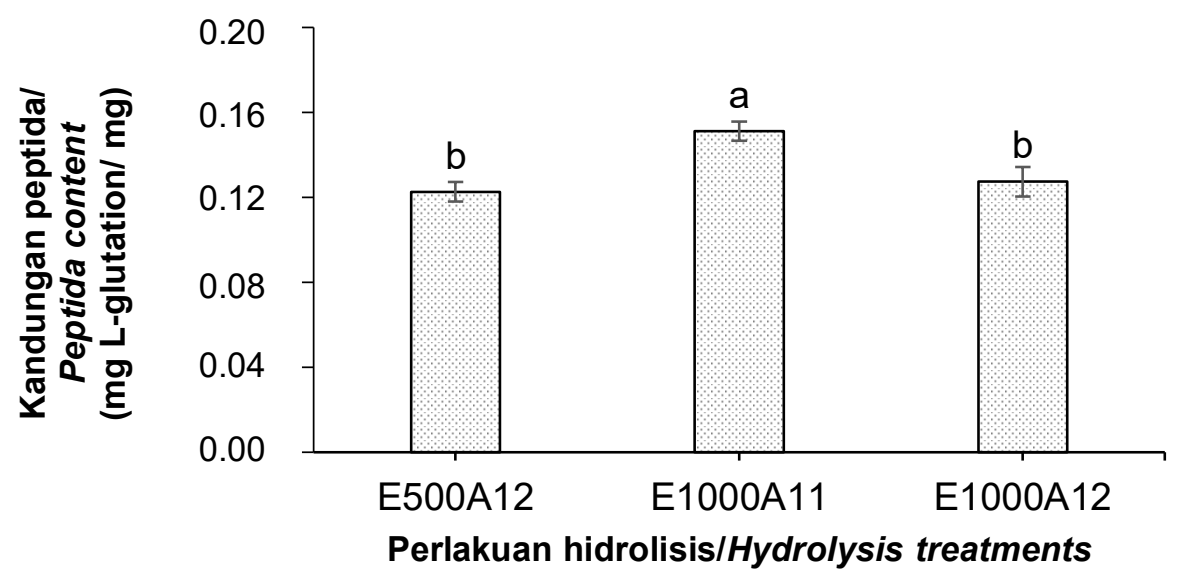

Keterangan/Notes: Perbedaan huruf pada grafik menunjukan perbedaan nyata $(p<0,05) /$ Different letters at the graph show significantly different with $p<0.05$

Gambar 3. Kandungan peptida HPI ikan kuniran dengan perlakuan hidrolisis konsentrasi enzim, dan perbandingan ikan dan air yang berbeda

Figure 3. Peptide content of FPH kuniran fish with different hydrolysis treatments of enzyme concentration and fish and water ratio

jumlah enzim yang berbeda diduga tidak memberikan profil berat molekul HPI yang berbeda. Pemberian enzim yang sama dan waktu inkubasi yang berbedabeda dilaporkan menghasilkan pola berat molekul hidrolisat yang sama (Benjakul \& Morrissey, 1997). Sebaliknya, penggunaan enzim yang berbeda akan menghasilkan profil molekul yang berbeda pula, walaupun dengan waktu yang sama (Benjakul \& Morrissey, 1997; Herpandi, Huda, Ahmad, \& Abdullah, 2016). Berat molekul HPI didominasi hidrolisat dengan ukuran 6,5-17,0 kDa, walaupun masih terdeteksi berat molekul diatas 17,0 dan dibawah $6,5 \mathrm{kDa}$ dengan

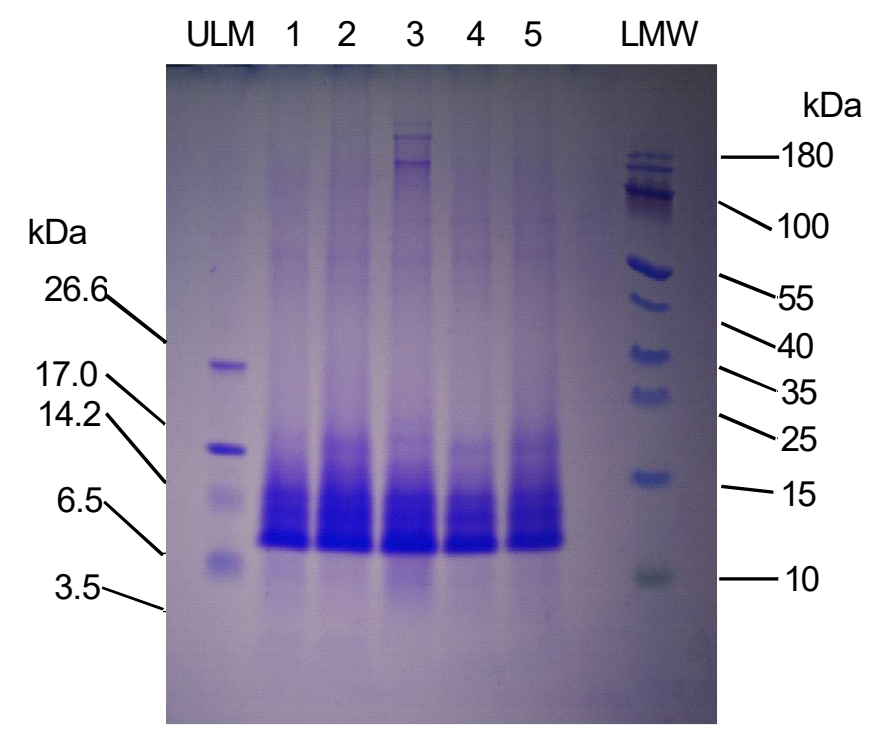

Keterangan/Notes: ULM: Ultra low molecular weight; 1: E500A12; 2 dan 3: E1000A11, 4 dan 5: E1000A12; LMW: Low molecular weight/ULM: Ultra low molecular weight; 1: E500A12; 2 dan 3: E1000A11, 4 dan 5: E1000A12; LMW: Low molecular weight

Gambar 4. Profil SDS-PAGE HPI ikan kuniran menggunakan gel akrilamid $16 \%$ dengan perlakuan hidrolisis konsentrasi enzim, dan perbandingan ikan dan air yang berbeda

Figure 4. SDS-PAGE profile of FPH kuniran fish from $16 \%$ of polyacrylamide gel with different hydrolysis treatments of enzyme concentration and fish and water ratio 
Tabel 4. Karakteristik fisik HPI ikan kuniran dengan perlakuan hidrolisis berbeda Table 4. Physical characteristics of FPH kuniran fish with different hydrolysis treatments

\begin{tabular}{cccc}
\hline $\begin{array}{c}\text { Karatketistik Fisik/ } \\
\text { Physical Characteristics }\end{array}$ & \multicolumn{2}{c}{ Perlakuan Hidrolisis/Hydrolysis Treatments } \\
\cline { 2 - 4 } & E500A11 & E1000A11 & E1000A12 \\
\hline Warna/Colour & & & \\
L & $94.27 \pm 0.14^{\mathrm{a}}$ & $94.66 \pm 0.43^{\mathrm{a}}$ & $94.85 \pm 0.40^{\mathrm{a}}$ \\
$\mathrm{a}$ & $-0.15 \pm 0.23^{\mathrm{a}}$ & $-0.50 \pm 0.04^{\mathrm{a}}$ & $-0.23 \pm 0.37^{\mathrm{a}}$ \\
$\mathrm{b}$ & $8.65 \pm 0.28^{\mathrm{a}}$ & $9.11 \pm 0.99^{\mathrm{a}}$ & $8.41 \pm 1.35^{\mathrm{a}}$ \\
\hline $\begin{array}{c}\text { Aktivitas emulsi/ } \\
\text { Emulsifying activity (\%) }\end{array}$ & $50.13 \pm 1.72^{\mathrm{a}}$ & $54.23 \pm 2.78^{\mathrm{a}}$ & $51.73 \pm 4.92^{\mathrm{a}}$ \\
\hline Stabilitas emulsi/ & $46.50 \pm 1.50^{\mathrm{a}}$ & $45.88 \pm 1.02^{\mathrm{a}}$ & $50.63 \pm 4.46^{\mathrm{a}}$ \\
\hline Emulsifying stability (\%) & &
\end{tabular}

Keterangan/Notes: Perbedaan huruf pada lajur yang sama menunjukan perbedaan nyata $(\mathrm{p}<0,05) / D$ ifferent letters at the same row show significantly different $(p<0.05)$

intensitas yang rendah. Berat molekul HPI tersebut lebih rendah daripada berat molekul jenis protein yang umum ditemukan dalam daging ikan seperti miosin $(200 \mathrm{kDa})$ dan aktin (45 kDa) (Kristinsson \& Rasco, 2000; Pacheco-Aguilar, Mazorra-Manzano, \& Ramírez-Suárez, 2008). Hal ini mengindikasikan bahwa enzim protease yang digunakan dalam penelitian ini bekerja dalam menghidrolisis daging ikan. Berat molekul HPI dari penelitian ini juga memiliki kemiripan dengan berat molekul HPI Pacific whiting (Merluccius productus) yang dihidrolisis menggunakan alkalase, yaitu didominasi oleh peptida dengan ukuran dibawah 20 kDa (Pacheco-Aguilar et al., 2008).

\section{Efek Perlakuan Hidrolisis terhadap Karakteristik Fisik HPI}

Pengaruh perbedaan hidrolisis terhadap sifat fisik HPI ikan kuniran ditunjukan pada Tabel 4. Secara umum karakter fisik dari HPI tidak dipengaruhi oleh perbedaan perlakuan hidrolisis $(p>0,05)$. Semua HPI mempunyai warna terang $(L=94,27-94,85)$, lebih cenderung biru $(a=-0,15--0,50)$ dan lebih cenderung kuning ( $b=8,41-9,11)$. Beberapa laporan menyebutkan bahwa perbedaan perlakuan hidrolisis menyebabkan perbedaan warna HPI yang dihasilkan. Penggunaan enzim alkalase dilaporkan mempengaruhi warna HPI dibandingkan dengan tanpa perlakuan hidrolisis (Foh, Kamara, Amadou, Foh, \& Xia, 2011). Pada penelitian ini, kesamaan warna dari masing-masing perlakuan kemungkinan disebabkan karena penggunaan jenis enzim yang sama. Warna HPI dari semua perlakuan ini lebih terang dibandingkan dengan HPI ikan Pacific whiting (M. productus) (Benjakul \& Morrissey, 1997) dan ikan lele (Clarias gariepinus) (Nurhayati, Nurjanah, \& Sanapi, 2013) yang dikering bekukan.

Aktifitas dan stabilitas emulsi HPI ikan kuniran masing-masing berkisar antara $50,13-54,23 \%$ dan $45,88-50,63 \%$. Nilai-nilai tersebut menunjukan tidak ada perbedaan sifat emulsi karena perbedaan perlakuan jumlah enzim dan air $(p>0,05)$. Secara umum, sifat emulsi dari HPI dipengaruhi oleh beberapa faktor, antara lain ukuran peptida, $\mathrm{DH}, \mathrm{pH}$, suhu, dan kekuatan ion (Kristinsson \& Rasco, 2000). Faktorfaktor tersebut selaras dengan hasil penelitian ini, yaitu ukuran berat molekul peptida dan DH dari masingmasing perlakuan memiliki kemiripan (Tabel 1 dan Gambar 5).

\section{KESIMPULAN}

Secara umum perlakuan hidrolisis ikan kuniran menggunakan enzim $1.000 \mathrm{U}$ dan perbandingan ikan dan air 1:1 (E1000A11) merupakan perlakuan terbaik yang terlihat dari kandungan protein, asam amino, peptida dan daya cerna tertinggi dibandingkan perlakuan lain. Karakteristik kimia dari HPI kuniran secara umum dipengaruhi oleh perbedaan perlakuan hidrolisis tetapi tidak sifat fisiknya. Perbedaan kandungan protein, abu, dan peptida dari HPI lebih dominan dipengaruhi oleh perbedaan perlakuan perbandingan ikan dan air, sedangkan kombinasi perlakuan jumlah enzim dan perbandingan ikan dan air berpengaruh terhadap kandungan asam amino dan daya cerna protein HPI. Kandungan asam amino dan daya cerna yang tinggi dari HPI ikan kuniran memberikan peluang aplikasi HPI sebagai penambah nutrisi bagi balita. 


\section{UCAPAN TERIMAKASIH}

Penelitian ini didanai DIPA Balai Besar Riset Pengolahan Produk dan Bioteknologi Kelautan dan Perikanan Nomor SP DIPA-032.12.2.403835/2017 melalui Penelitian Teknologi Produksi Hidrolisat Protein Ikan Secara Enzimatis. Terimakasih kepada Agusman yang telah membantu dalam analisis statistik dan Benget R. Simanjuntak yang telah membantu menyediakan enzim protease.

\section{DAFTAR PUSTAKA}

Ariyani, F., Saleh, M., Tazwir, T., \& Hak, N. (2003). Optimasi Proses Produksi Hidrolisat Protein Ikan (HPI) dari Mujair (Oreochromrb mossambicusl). Jurnal Penelitian Perikanan Indonesia, 9(5), 11. doi: 10.15578/jppi.9.5.2003.11-21

Auwal, S. M., Zarei, M., Abdul-Hamid, A., \& Saari, N. (2017). Optimization of bromelain-aided production of angiotensin l-converting enzyme inhibitory hydrolysates from stone fish using response surface methodology. Marine Drugs, 15(4), 104. doi: 10.3390/ md15040104

Benjakul, S., \& Morrissey, M. T. (1997). Protein hydrolysates from Pacific whiting solid wastes. Journal of Agricultural and Food Chemistry, 45(9), 3423-3430. doi: 10.1021/jf970294g

Badan Standardisasi Nasional (BSN). (2010). SNI 012354- (2010). Cara Uji Kimia pada Produk Perikanan. Jakarta.

Badan Standardisasi Nasional (BSN). (2015). SNI 012354- (2015). Cara Uji Kimia pada Produk Perikanan. Jakarta.

Badan Standardisasi Nasional (BSN). (2017). SNI 012354- (2017). Cara Uji Kimia pada Produk Perikanan. Jakarta.

Chalamaiah, M., Hemalatha, R., \& Jyothirmayi, T. (2012). Fish protein hydrolysates: proximate composition, amino acid composition, antioxidant activities and applications: a review. Food Chemistry, 135(4), 30203038. doi: 10.1016/j.foodchem.2012.06.100

Fawzya, Y. N., Chasanah, E., Martosuyono, P., Zilda, D. S., Susilowati, R., Oktavia, D. A., ... Patantis, G. (2017). Laporan Teknis Penelitian Teknologi Produksi Hidrolisat Protein Ikan Secara Enzimatis. Jakarta.

Fernandes, P. (2016). Enzymes in fish and seafood processing. Frontiers in Bioengineering and Biotechnology, 4, 59. doi: 10.3389/fbioe.2016.00059

Foh, M. B. K., Kamara, M. T., Amadou, I., Foh, B. M., \& Xia, W. (2011). Chemical and physicochemical properties of tilapia (Oreochromis niloticus) fish protein hydrolysate and concentrate. International Journal of Biological Chemistry, 5(1), 21-36. doi: 10.3923/ ijbc.2011.21.36

García Moreno, P. J., Pérez Gálvez, R., Espejo Carpio, F. J., Ruiz Quesada, C., Pérez Morilla, A. I., Martínez Agustín, O., ... Guadix, E. M. (2017). Functional, bioactive and antigenicity properties of blue whiting protein hydrolysates: effect of enzymatic treatment and degree of hydrolysis. Journal of the Science of Food and Agriculture, 97(1), 299-308. doi: 10.1002/ jsfa.7731

Gehrt, A. J. (1971). Pepsin-Digestibility Method for Animal Proteins. Journal of the Association of Official Analytical Chemists, 54(3), 669-680. doi: 10.1093/ jaoac/54.3.669

Haider, S. R., Reid, H. J., \& Sharp, B. L. (2012). Tricinesds-page. In Protein electrophoresis (pp. 81-91). Springer.

He, S., Franco, C., \& Zhang, W. (2013). Functions, applications and production of protein hydrolysates from fish processing co-products (FPCP). Food Research International, 50(1), 289-297. doi: 10.1016/ j.foodres.2012.10.031

Herpandi, Huda, N., Ahmad, R., \& Abdullah, W. N. W. (2016). Protein quality of hydrolyzed dark muscle protein of skipjack tuna (Katsuwonus pelamis). Turkish Journal of Fisheries and Aquatic Sciences, 16(1), 177-186. doi; 10.4194/1303-2712-v16_1_18

Hoyle, N. T., \& Merritt, J. H. (1994). Quality of fish protein hydrolysates from herring (Clupea harengus). Journal of Food Science, 59(1), 76-79. doi: 10.1111/j.13652621.1994.tb06901.x

Hutchings, J. B., Luo, M. R., \& Ji, W. (2012). Food appearance and expectations. Color in Food: Technological and Psychophysical Aspects, 3-10.

Kementerian Kelautan dan Perikanan. (2021). Statistik Produksi Perikanan. Retrieved August 22, 2021, from h t t p s : / / s t a t i s t i k.k k p.go.id/ home.php?m=total\&i=2\#panel-footer

Kristinsson, H. G., \& Rasco, B. A. (2000). Fish protein hydrolysates: production, biochemical, and functional properties. Critical Reviews in Food Science and Nutrition, 40(1), 43-81. doi: 10.1080/ 10408690091189266

Martosuyono, P., Fawzya, Y. N., Patantis, G., \& Sugiyono, S. (2019). Enzymatic production of fish protein hydrolysates in a pilot plant scale. Squalen Bulletin of Marine and Fisheries Postharvest and Biotechnology, 14(2), 85-92. doi: 10.15578/ squalen.v14i2.398

Nielsen, P. M., Petersen, D., \& Dambmann, C. (2001). Improved method for determining food protein degree of hydrolysis. Journal of Food Science, 66(5), 642646. doi: 10.1111/j.1365-2621.2001.tb04614.x

Nollet, L. M. L., \& Toldrá, F. (2012). Food analysis by HPLC. CRC press.

Noman, A., Xu, Y., AL-Bukhaiti, W. Q., Abed, S. M., Ali, A. H., Ramadhan, A. H., \& Xia, W. (2018). Influence of enzymatic hydrolysis conditions on the degree of hydrolysis and functional properties of protein hydrolysate obtained from Chinese sturgeon (Acipenser sinensis) by using papain enzyme. Process Biochemistry, 67, 19-28. doi: 10.1016/ j.procbio.2018.01.009

Nurhayati, T., Salamah, E., Cholifah, , \& Nugraha, R.. (2014). Optimasi Proses Pembuatan Hidrolisat Jeroan Ikan Kakap Putih. Jurnal Pengolahan Hasil 
Perikanan Indonesia, 17(1), 42-52. doi: 10.17844/ jphpi.v17i1.8136

Nurhayati, T., Nurjanah, \& Sanapi, C. H. (2013). Karakterisasi hidrolisat protein ikan lele dumbo (Clarias gariepinus). Jurnal Pengolahan Hasil Perikanan Indonesia, 16(3), 207-214. doi: 10.17844/jphpi.v16i3.8058

Pacheco-Aguilar, R., Mazorra-Manzano, M. A., \& RamírezSuárez, J. C. (2008). Functional properties of fish protein hydrolysates from Pacific whiting (Merluccius productus) muscle produced by a commercial protease. Food Chemistry, 109(4), 782-789. doi: 10.1016/j.foodchem.2008.01.047

Prasetyo, D. Y. B., Sarmin, S., Setyastuti, A. I., \& Kurniawati, A. (2020). Pengaruh perbedaan enzim proteolitik dan lama hidrolisa terhadap kualitas hidrolisat protein ikan dari limbah industri fillet Ikan Nila (Oreochromisniloticus (Linnaeus, 1758)). Jurnal IImu Kelautan Kepulauan, 3(2). doi: 10.33387/ jikk.v3i2.2586

Putalan, R., Munifah, I., Nurhayati, T., \& Chasanah, E. (2018). Antioxidant and ace inhibitor potential of stripe trevally fish (Selaroides leptolepis) hydrolysate. Squalen Bulletin of Marine and Fisheries Postharvest and Biotechnology, 13(1), 1722. doi: 10.15578/squalen.v13i1.319

Siddik, M. A. B., Howieson, J., Fotedar, R., \& Partridge, G. J. (2021). Enzymatic fish protein hydrolysates in finfish aquaculture: a review. Reviews in Aquaculture, 13(1), 406-430. doi: 10.1111/raq.12481
Srikanya, A., Dhanapal, K., Sravani, K., Madhavi, K., \& Praveen, K. G. (2017). A study on optimization of fish protein hydrolysate preparation by enzymatic hydrolysis from tilapia fish waste mince. Int.J.Curr.Microbiol.App.Sci., 6(12), 3220-3229. doi: 10.20546/ijcmas.2017.612.375

Utomo, B. S. B., Suryanigrum, T. D., \& Harianto, H. R. (2014). Optimization of enzymatic hydrolysis of fish protein hydrolysate $(\mathrm{FPH})$ processing from waste of catfish fillet production. Squalen Bulletin of Marine and Fisheries Postharvest and Biotechnology, 9(3), 115-126. doi: 10.15578/squalen.v9i3.79

Volkert, M. A., \& Klein, B. P. (1979). Protein dispersibility and emulsion characteristics of four soy products. Journal of Food Science, 44(1), 93-96. doi: 10.1111/ j.1365-2621.1979.tb10014.x

Wiadnyana, N. N., Badrudin, B., \& Aisyah, A. (2017). Tingkat pemanfaatan sumber daya ikan demersal di wilayah pengelolaan perikanan laut Jawa. Jurnal Penelitian Perikanan Indonesia, 16(4), 275-283. doi: 10.15578/jppi.16.4.2010.275-283

Witono, Y., Maryanto, M., Taruna, I., Masahid, A. D., \& Cahyaningati, K. (2020). Aktivitas antioksidan hidrolisat protein ikan wader (Rasbora jacobsoni) dari hidrolisis oleh enzim calotropin dan papain. Jurnal Agroteknologi, 14(01), 44-57. doi: 10.19184/j-agt.v14i01.14817

Zamora-Sillero, J., Gharsallaoui, A., \& Prentice, C. (2018). Peptides from fish by-product protein hydrolysates and its functional properties: An overview. Marine Biotechnology, 20(2), 118-130. doi: 10.1007/s10126-018-9799-3 